\title{
Managements of ankylosed incisor occurred during adolescence using alveolar bone distraction osteogenesis and decoronation: case report
}

\author{
Eun-young Kwon', Woo-Sung Son², Soo-Byung Park², Seong-sik Kim², Yong-il Kim², Youn-kyung Choi* \\ 'Dental Clinic Center, Pusan National University Hospital, Busan, Republic of Korea \\ ${ }^{2}$ Department of Orthodontics, School of Dentistry, Pusan National University, Yangsan, Republic of Korea
}

One of the common complications of dental injury is tooth ankylosis. Unlike adults, when tooth ankylosis occurs in the adolescents, ankylosis interfered the growth of the adjacent alveolar bone, resulting in the developmental failure of the alveolar bone and subsequent open bite. The most common treatment option for ankylosed tooth is extraction. However, when prognosis of ankylosed tooth after extraction is expected to be poor due to severity of infrapositioning or prosthetic replacement cannot be performed immediately, various treatment options should be considered. This report suggests multidisciplinary treatment that might bring functionally and esthetically favorable result included alveolar bone distraction osteogenesis and decoronation of ankylosed maxillary anterior tooth with orthodontic and prosthetic treatments. (J Dent Rehabil Appl Sci 2017;33(2):143-53)

Key words: ankylosed tooth; infraocclusion; alveolar bone distraction osteogenesis; decoronation

\begin{abstract}
서론
치아 외상은 지역에 따른 차이는 있으나, 학령기의 $1 / 4$, 성인의 $1 / 3$ 정도에서 영구치 외상을 경험하며, 9 - 10 세경 가장 많이 경험하는 것으로 알려져 있다. ${ }^{1}$ 외상에 의 한 치아 손상은 주로 전치에 발생하며 남성에서 더 흔하 다. 이 중 $0.5-3.0 \%$ 에서 탈구를, $0.5-1.9 \%$ 에서 함입성 변위를 경험하였다고 알려져 있으며 가장 흔한 합병증은 치아 유착이다. ${ }^{2}$

치아 유착은 치조골과 치근 표면의 비정상적 유합으 로 정의된다. ${ }^{3}$ 치아 유착의 발생 기전은 외상 등으로 치 주인대가 손상되면, 치유 과정에서 비정상적으로 치조골 로 대체되고, 이후 점진적 치근 외흡수가 나타나 발생한 다. 이로 인해 치아의 생리적 혹은 교정적 이동이 제한되 어, 저작 및 교합상의 문제를 야기한다. 대표적으로 나타
\end{abstract}

*Correspondence to: Youn-kyung Choi

Clinical Assistant Professor, Department of Orthodontics, Pusan National University Hospital University, 179 Gudeok-ro, Seo-gu, Busan, 49241, Republic of Korea Tel: +82-51-240-7430, Fax: +82-51-240-7706, E-mail: youngyng@hanmail.net Received: January 10, 2017/Last Revision: March 6, 2017/Accepted: April 18, 2017
나는 구강 내 소견은 유착치의 저위와 인접치아의 저위된 유착치 상방으로의 경사이다.

치아 유착은 발생 시기에 따라 국소적인 치아 치조골 영역뿐 만 아니라 두개 안면 영역까지도 광범위하게 영 향을 끼칠 수 있다. 특히 성장기 아동에서 유착이 발생 할 경우 치조골 성장이 저해되어 전치부 또는 구치부 개 방교합이 발생한다. 이로 인해 치열 및 안모의 정중선 변 위, 개방교합에 따른 수직적 안모 변화로 인한 비심미적 인 안모 및 미소선을 보이며 저작 기능 장애까지 유발하 게 된다. 따라서 조기에 감별 진단하여 개개인에 맞는 치 료 계획을 수립하는 것이 중요하다. ${ }^{4}$

유착치 치료에 있어 가장 흔히 시행되는 것은 발치이 다. ${ }^{2}$ 성장기 아동에서 유착된 치아를 발치 하는 것은 해 당 영역에서 치조골의 성장을 저해하는 요인을 제거하 고, 인접 치아들의 계속되는 맹출과 이에 따른 인접 치주

Copyright@ 2017 The Korean Academy of Stomatognathic Function and Occlusion. (c) It is identical to Creative Commons Non-Commercial License. 
조직의 정상적인 성장을 유도할 수 있어 결손부위 치조 골의 성장을 도와준다. 그러나 유착 치아의 저위가 심하 거나, 향후 보철 수복까지 오랜 시간이 남았을 경우, 단 순히 발치를 시행하면 치조골 및 치주조직의 결손 정도 가 심해질 수 있으므로 다양한 치료방법이 고려되어야 한다.

여러 가지 방법 중 단일 치아 절단술(single tooth osteotomy)을 동반한 치조골 신장술(alveolar bone distraction osteogenesis)이 고려될 수 있다. ${ }^{5,6}$ 이 방법은 유착치를 포함한 치조골을 절단한 후, 3 차원적으로 이동 시켜, 치조골을 유도하여, 심미적인 위치로 치아 및 치조 골을 재위치 시킬 수 있는 장점이 있다. 그러나 치조골 신 장술 이후, 치근과 인접 치조골의 유착은 여전히 남을 수 있으며, 만기 치조골의 잔여 성장에 의해 치조골의 수직 적 위치 차이가 다시 발생할 수 있다.

본 증례에서는 성장기 아동에서 유착치 치료의 한 방 법으로 적용한 치조골 신장술 후에 나타난 수직적 재발 (open bite)과 유착치의 치근 외흡수를 치관 절제술 등을 포함한 다분야 협력치료를 통하여 적절히 해결한 증례를 보고하고자 한다.

\section{증례보고}

\section{환자 개요 및 진단}

최초 11세 11개월에 본원에 내원한 여아로, 7세 때 책 상 모서리에 부딪혀 상악 중절치(\#11, 21)에 외상을 입 었다. 당시, 절치들은 재식되었으나, 점차 좌측 중절치 (\#21)가 유착되었다. 내원 당시, 구내 임상 소견상, 외상 이후 발생한 상악 좌측 중절치 유착으로 인해, 치조골의 성장이 저해되었다. 이로 인해 전치부 개방교합이 발생하 였으며, 인접치아의 유착 치아로의 쓰러짐이 관찰되었다. 좌측 중절치에서 $8 \mathrm{~mm}$ 이상, 우측 중절치에서도 $1 \mathrm{~mm}$ 의 개방 교합이 관찰되었다(Fig. 1).
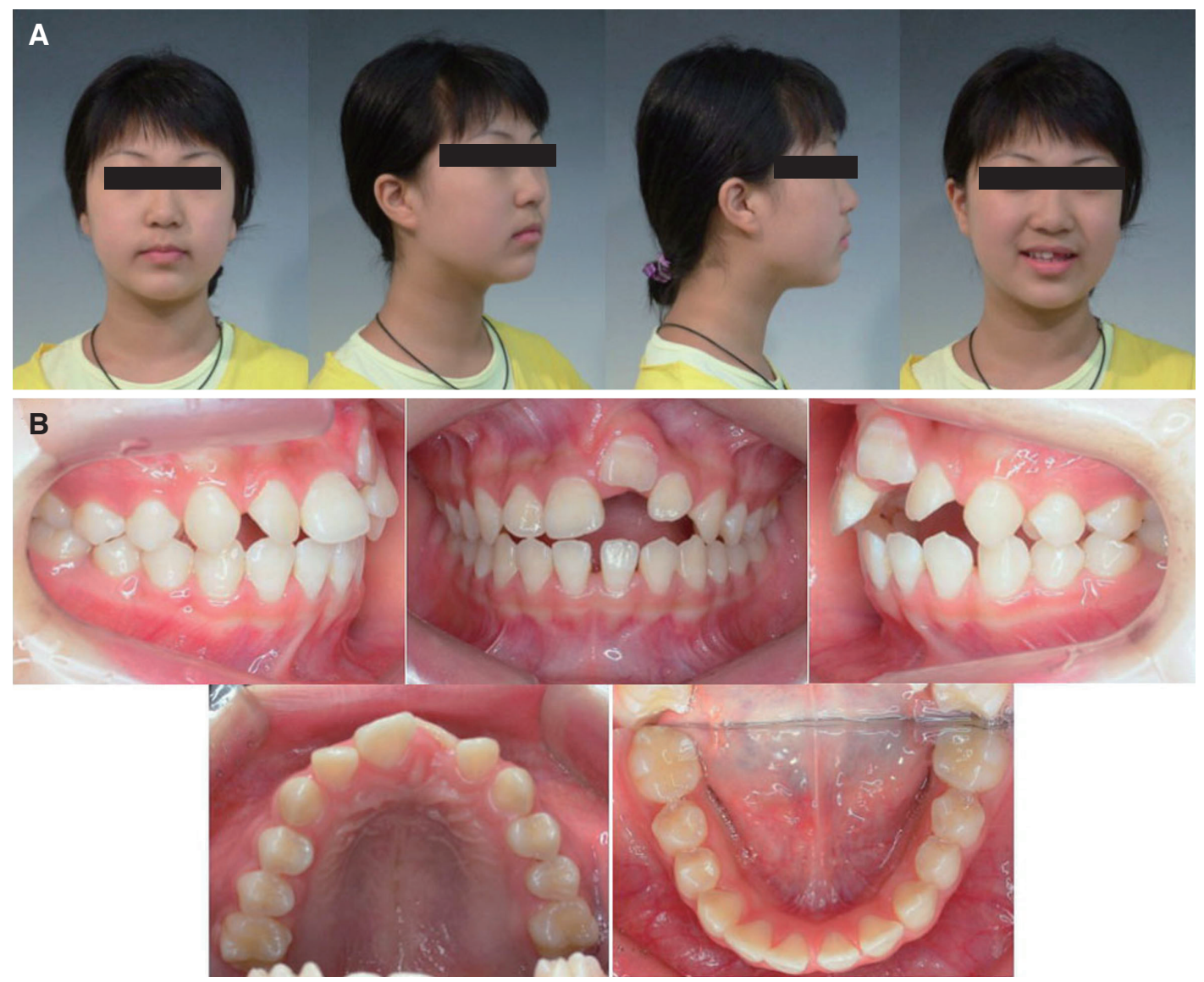

Fig. 1. (A) Pretreatment extraoral and intraoral photographs ( $1^{\text {st }}$ treatment). The patient was 11 years old. (B) \#21 was ankylosed and located infraocclusionly more than $8 \mathrm{~mm}$ due to trauma at 7 years. Anterior open bite was observed. 
방사선학적 소견에서 치주인대강의 소실과 치경부에 서의 미약한 치근 외흡수가 관찰되었다. 외상 기왕력과 방사선학적 소견, 임상 소견 등을 토대로 상악 좌측 중절 치의 유착으로 진단하였다. 전후방적 골격 평가에서는, II급 견치 관계가 관찰되고, ANB 7.9도의 skeletal Class II division 1 malocclusion이라고 평가되었다. 측모 두부 규격 방사선 사진에서 CVM stage 5 로 평가하여, 최대성 장 급등기를 지났으리라 판단하였다(Fig. 2).

다양한 치료 방법이 고려될 수 있으나, 환자의 나이와 기능적, 심미적 목적을 위해서 통상적인 발치 및 보철치료 는 제외되었다. 상악 중절치와 주위 치주조직의 수직적 위 치를 개선하기 위해 몇 가지 치료법을 고려해볼 수 있었다.

첫 번째는 이환된 단일 치아를 외과적으로 재위치하여, 인접치아와 수직적 위치를 맞추는 것이다. 그러나 이 경 우, $8 \mathrm{~mm}$ 이상의 과도한 치아 위치 변화가 요구되었고, 그로 인한 치은연의 수직적 차이로 비심미적 결과가 야기 될 것이라고 판단되었다.

두 번째로, 이러한 광범위한 치아 이동이 요구될 때 고 려해볼 수 있는 치조골 신장술(alveolar bone distraction osteogenesis)이다. 이 방법은 많은 양의 골편의 이동도 가능하며, 경조직뿐 만 아니라 연조직도 함께 리모델링 되어, 치은 피개도 함께 개선될 수 있는 장점이 있다. 따

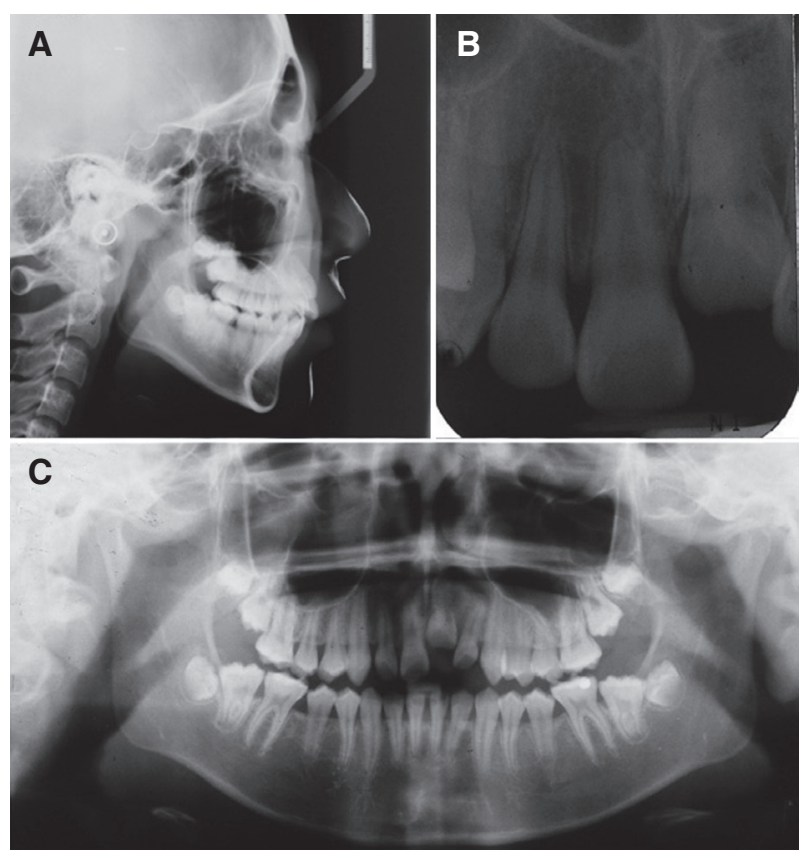

Fig. 2. (A) Pretreatment lateral cephalograph, periapical and panoramic radiographs ( $1^{\text {st }}$ treatment). (B) Lamina dura of \#21 was disappeared in radiographic. (A - C) \#21 was located infraocclusionly
라서 유착된 좌측 중절치의 치조골 신장술을 시행하기로 하였다.

구치부 교합 개선 및 중절치 공간 확보를 위한 교정치 료 먼저 시행한 후 교정용 expansion screw를 변형하여 customized tooth-borne alveolar bone distractor를 제 작하였다(Fig. 3). 이후, 장골의 골신장술과 마찬가지로, 유착치를 포함한 치조골 절단술을 시행하고, 5 일간의 휴 지기를 거친 후, 골을 신장하였다. 치조골 신장은 하루에 $0.5-1.0 \mathrm{~mm}$ 를 신장하는 것을 권고하므로, ${ }^{7}$ 조직 저항이 강할 것이라 예상되는 초기 4일간은 하루에 $1.0 \mathrm{~mm}$ 를 신장하고, 이후에는 조직 생성을 위해서 속도를 늦춰 하 루에 $0.5 \mathrm{~mm}$ 만큼 신장하였다. 사용된 expansion screw 는 1번 활성화 시, $0.25 \mathrm{~mm}$ 확장되므로, 원하는 만큼 정 확한 양을 조절할 수 있었다. 향후 재발을 고려하여 1 $\mathrm{mm}$ 를 과신장시켰다. 이후, 2주간 경화기를 거쳐 유착치 아의 위치를 개선, 치료를 마무리하였다. 전체 치료 기간 은 13 개월이었으며, 종료 시 환자의 나이는 13 세 2 개월이 었다(Fig. 4).

유지 평가 기간 동안, 구치부 관계는 양호하게 유지되 었으나, 전치부에서 유착치 인접 치조골의 수직적 성장이 지속되었고, 점차 인접치와의 절단연의 차이가 발생하여, 전치부 개방교합이 나타났다. 치조골의 성장 저해로 치 은연 역시 수직적 차이가 나타났다. 6년의 유지 기간 이 후, 환자의 나이가 18 세 3 개월이 되었을 때, 좌측 중절치 에서 $2 \mathrm{~mm}$ 의 개방교합이 관찰되어 재교정 치료를 시행 하기로 하였다(Fig. 5).

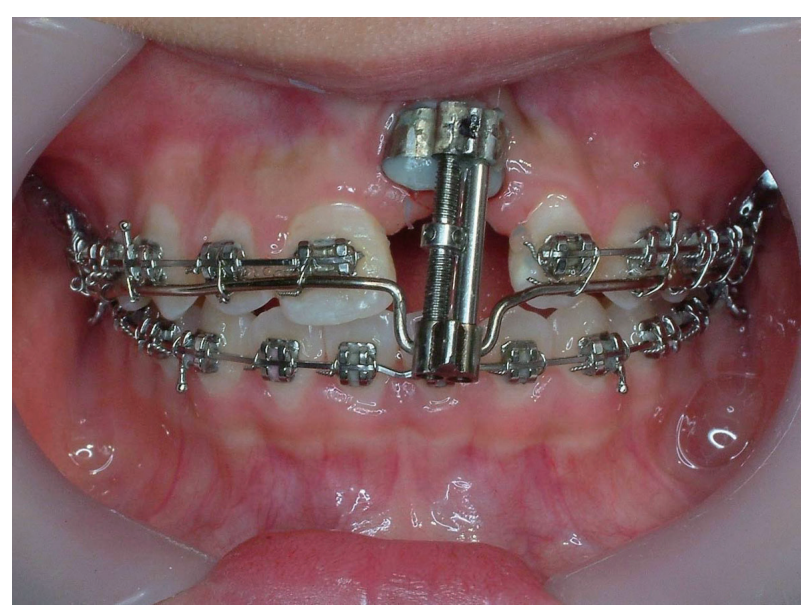

Fig. 3. Intraoral appliance for \#21 distraction osteogenesis after single tooth osteotomy. Distraction was carried out $0.5-1.0 \mathrm{~mm}$ per day. 

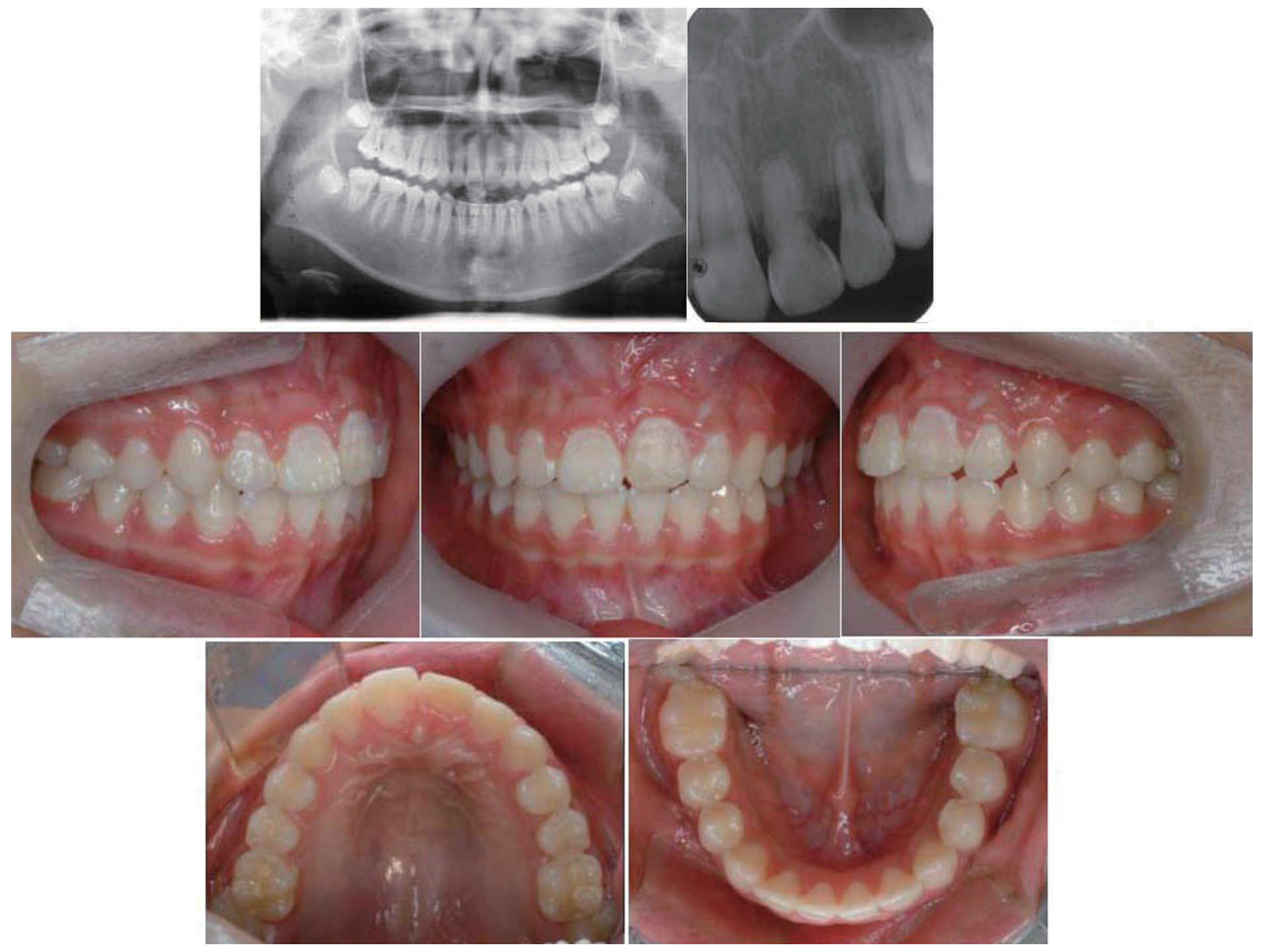

Fig. 4. Posttreatment intraoral photographs, panoramic and periapical radiographs ( $1^{\text {st }}$ treatment).
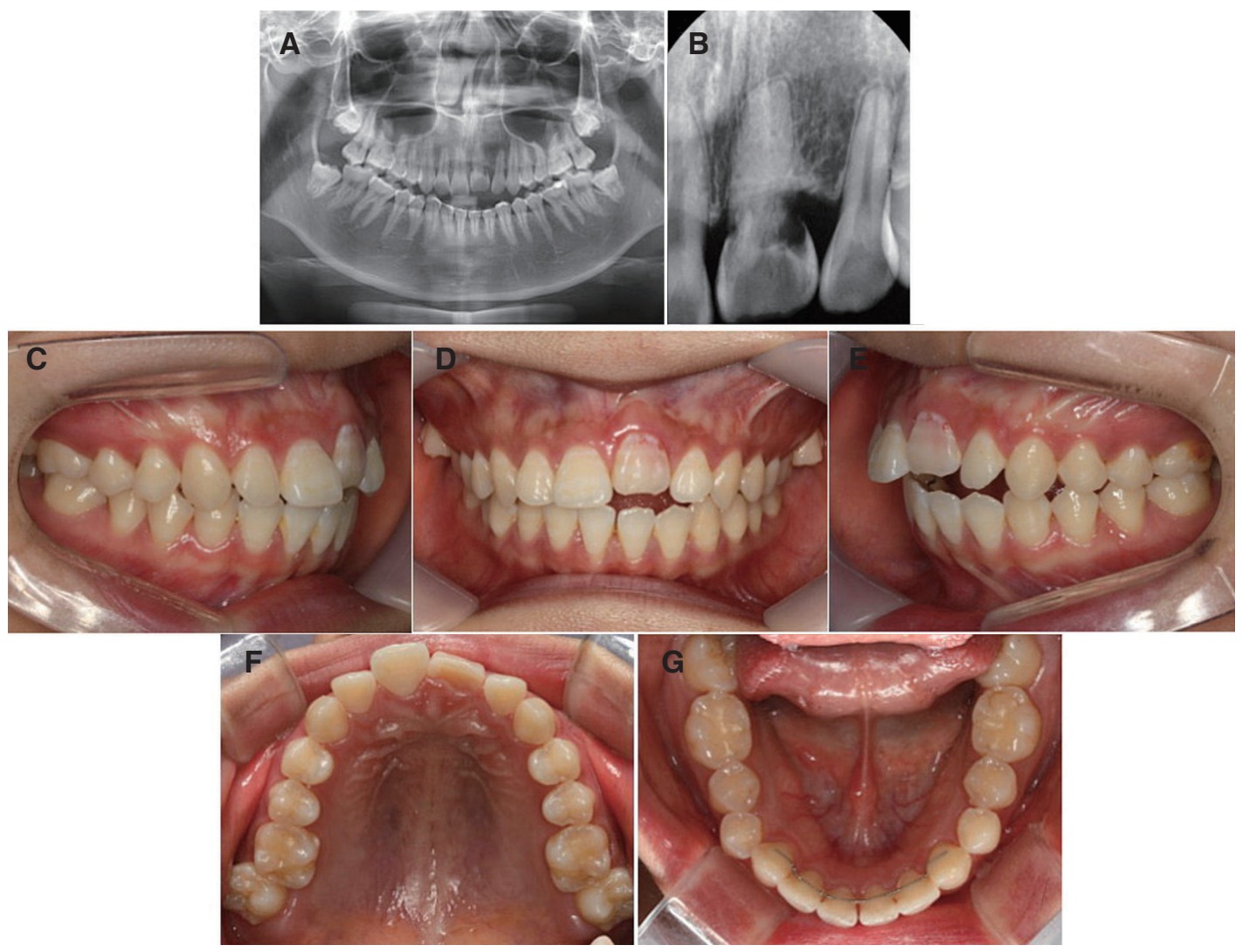

Fig. 5. (A, B) Follow-up (after 6 years) photographs, panoramic and periapical radiographs. The external root resorption on \#21 was occurred. (C - G) The vertical position of \#21 was infraocclusion and pink spot of cervical area was observed. 
구내 임상소견에서 상악 좌측 중절치 치경부에 pink spot이 관찰되었으며, 좌우 중절치의 치은연 수직적 높이 의 차이가 나타났다. 수평 피개교합은 $4 \mathrm{~mm}$ 였으며, 좌 측 전치부에서 개방교합이 나타났다. 좌측에서 II급 견치 및 구치 관계였다. 상하악 제 2 대구치가 이소맹출 되었다. 방사선학적 소견을 보면 파노라마 상, 상악 좌측 중절치 의 저위로 인해 해당 치조골의 성장 저해가 나타나고, 중 절치 치경부 치근 외흡수가 관찰되었다. 측모 두부계측 방사선 사진상, 하악골이 후방에 위치한 skeletal Class II division 1이었으며, 수직적으로 hyperdivergent skeletal pattern을 보였다. 상,하악 전치는 순측 경사되었다.

\section{치료 목표}

치료의 목표는 교합을 개선하고, 전치부 개방교합을 해소하여, 보다 심미적인 결과를 얻는데 두었다.

성인에서 유착 치아로 인한 전치부 개방교합의 개선은 3 가지 방법이 선택될 수 있었다.

첫 번째로 유착치아를 그대로 두고, 보철수복을 통해 개방교합을 개선하는 것이다. 그러나 본 증례에서는, 유 착치의 치경부 외흡수가 나타나 장기적인 치아의 예후가 좋지 않을 것이라 예상되었다. 또한 보철 수복을 통해 인 접치와 절단연을 일치시킬 경우 치아의 외형이 길어지고, 치은연의 수직적 위치 차이 등 비심미적인 결과가 예상되 었다.
또 다른 방법으로 유착치아의 발치 후 교정 및 보철치 료를 선택할 수 있으나, 발치로 인한 치조골의 퇴축으로 향후 임플란트 수복에 어려움이 있으리라 판단되었다.

이에 심미적인 보철 수복이 가능하도록 치조골을 최대 한 보존하기 위해 발치 대신 교정치료와 함께 치관 절제 술(decoronation)을 시행하기로 하였다. 치관 절제술은 점막골막피판(mucoperiosteal flap)을 형성하고 치관을 제거한 치근을 잔존시켜, 새로운 치조골이 형성될 수 있 도록 하는 술식이다. ${ }^{8}$ 건전한 치근이 잔존될 경우, 염증반 응은 미약하게 나타나며, 치근이 새로운 뼈 형성을 위한 매개체로서 치조골을 유지시켜, 향후 더욱 심미적인 보철 수복이 가능할 수 있다. ${ }^{9}$ 따라서 치료 계획은 교합관계 개선을 위한 교정치료를 먼저 시행하고, 좌측 중절치 치 관을 제거하는 치관절제술을 통해 치조골을 유지, 임플 란트 수복으로 마무리하기로 하였다.

\section{치료 과정}

좌측 상악 중절치를 제외한 치아들에 022' 슬롯의 브 라켓을 부착하여 적절한 수직피개 및 수평피개를 형성하 고, 구치 관계를 개선하고자 하였다. II급 견치 및 구치 관계 개선을 위해서 상악 제 2 소구치와 제 1 대구치 사이에 골성고정원(miniscrew)을 식립하고, 이를 고정원으로 이 용하여 전체 치열을 후방 이동하였다(Fig. 6).

교합관계 개선이 어느 정도 완료된 교정 치료 7 개월

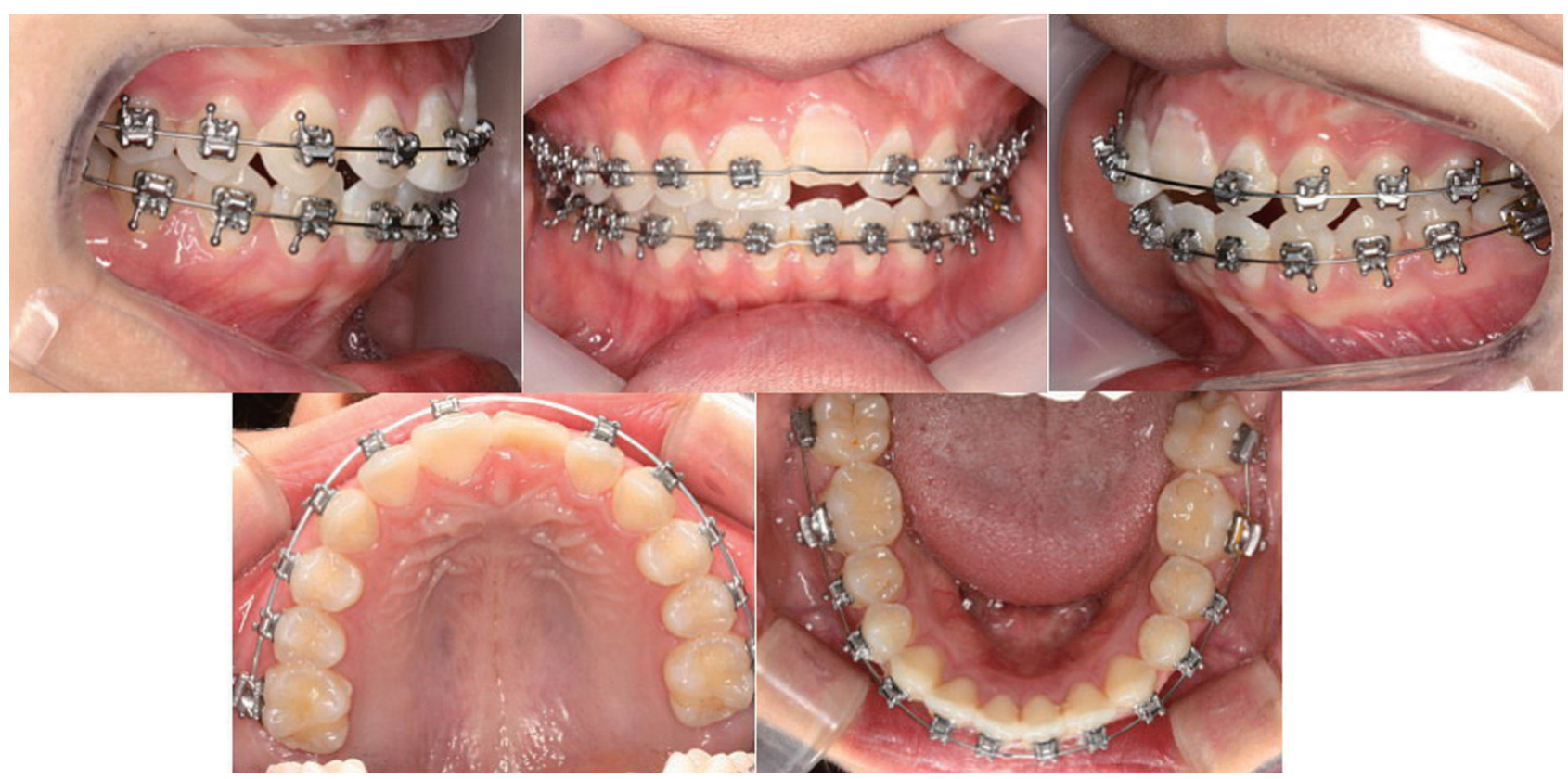

Fig. 6. Intraoral photographs during orthodontic treatment ( $2^{\text {nd }}$ treatment). 
째에, 유착치의 치관 절제술을 시행하기로 하였다. 국소 마취 하에 점막골막피판을 형성하고, high-speed rotary handpiece를 사용하여 상악 좌측 중절치의 치관을 삭제 하였다. 치은이 치조골을 덮을 수 있도록 치경부에서 치 관을 제거하였다. 이 때 치조골의 생성을 도모하기 위해 치근은 치조골 하방 $2 \mathrm{~mm}$ 까지 제거하고, 나머지 치근 부 위는 치조골 내에 남겨두었으며, 치수 내부 조직을 제거 하고 혈병이 형성되는 것을 확인하였다. 추가적인 각화치 은 형성을 도와 주기 위해서 설측판막을 좀 더 협측으로 당겨 봉합하였다. 절단된 유착 치아의 치관을 치조정에 맞게 조정하고, 호선에 부착하여 공간유지를 위한 임시
치아로 사용하였다(Fig. 7). 술 후 교정치료 기간 동안, 임 시치아를 치조정에 맞게 주기적으로 재조정하였다.

술 후 5 개월 뒤, 치관절제술을 시행한 부위의 치은이 치유된 것을 확인하고, 잔존치근을 발거하여 임플란트를 바로 식립하려 했으나, 협측 치조골 두께가 얇아 식립 후 심한 치조골 흡수가 예상되었다. 따라서, 협측에 bovine bone material (Bio-Oss ${ }^{\circledR}$, Geistlich Pharmaceutical, Wolhusen, Switzerland)과 collagen membrane (BioGide $^{\circledR}$, Geistlich Pharmaceutical, Switzerland)를 이용하 여 치조골 재생술 $(\mathrm{GBR})$ 을 시행하여 치조골을 보강하였 다(Fig. 8).

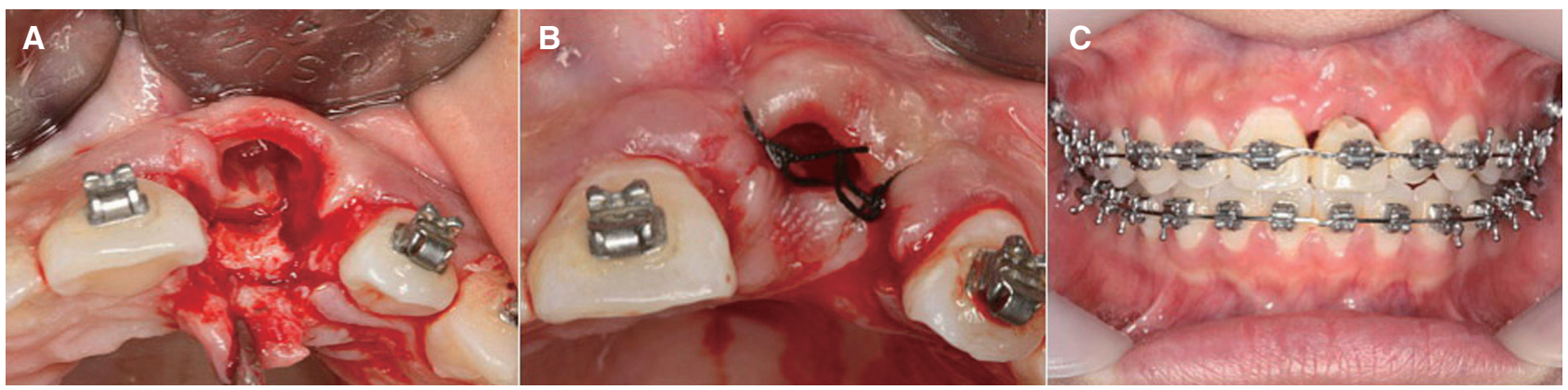

Fig. 7. Procedure of decoronation. (A, B) In order to create new marginal bone, the coronal part of the root surface was removed $2 \mathrm{~mm}$ below the marginal bone (C). The crown part of \#21 was adjusted and placed like an artificial tooth.
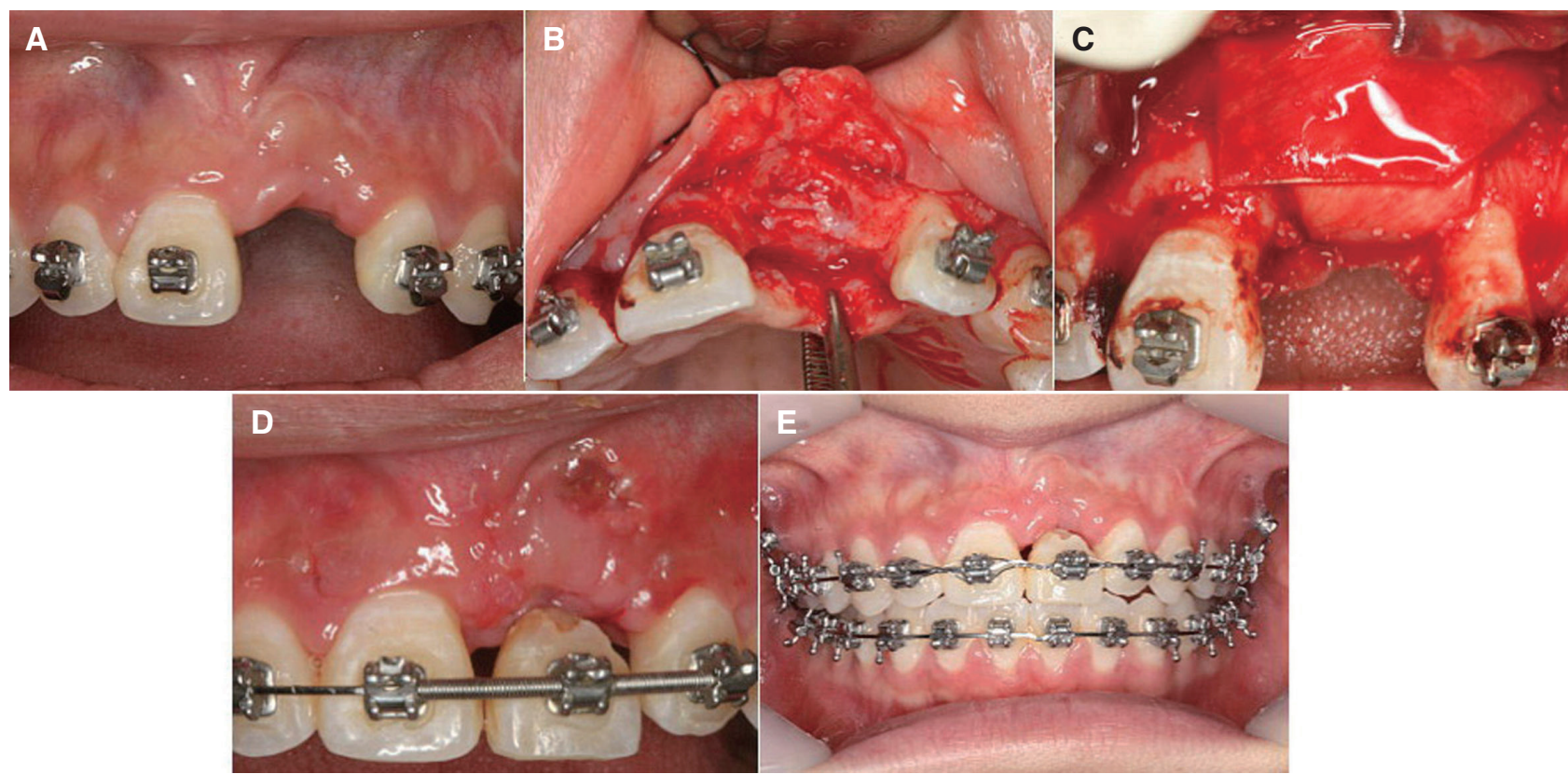

Fig. 8. Extraction of the root rest and GBR procedure. (A, B) Remaining buccal alveolar bone thickness was too thin. (C) Guided bone regeneration procedure was performed on buccal area with bovine bone material and collagen membrane. (D, E) The crown part of \#21 was used like an artificial tooth and adjusted to alveolar crest contour. 
6개월 뒤, 수술 과정에서 협측에 $2 \mathrm{~mm}$ 이상의 잔존골 이 확보되면서 치조골 열개, 천공 등이 관찰되지 않아 별 도의 GBR 없이 $3.5 \times 11.5 \mathrm{~mm}$ fixture (Osstem, Seoul, Korea)를 식립하였다. 수술시에 연조직 형태 향상 위해 추가적으로 협측면에 결합조직 이식술 시행하였다(Fig. 9). 임플란트 식립 5개월 뒤, 연조직 형태가 양호함을 확 인 후 healing abutment를 체결 하였다. 이후 1 개월 뒤 임 시 보철수복을 실시하였으며 10개월 뒤 최종 보철 수복 을 시행하였다. 전체 치료기간은 24개월이었다.

\section{치료 결과}

구내 소견 상, 유착으로 저위되었던 상악 좌측 중절치 가 발거되고, 전치부 개방교합이 개선되고 중절치 치은연 의 좌우 높이도 개선되었다. 그러나 여러 번의 임시치관 수정에도 상악 좌측 중절치 치은연의 rolling이 나타났는 데, 이는 여러 차례 수술로 인한 반흔 형성과 다소 구개 측으로 식립된 임플란트 fixture에 의한 것으로 판단된다. 이소 맹출했던 상하악 제2대구치 역시 악궁내로 배열되 었다.

상악 전체 치열의 후방 이동을 시행한 결과, 순측 경사 되었던 상악 전치 각도가 개선되어, 양호한 상하악 절치 간 각도 및 교합이 형성되었다. 측모 사진 상, 과도했던 수평피개가 $2.3 \mathrm{~mm}$ 로 개선되었으며, 측모 또한 양호하
였다(Fig. 10).

\section{고찰}

성장 완료 전 치아 유착과 이로 인한 저위가 발생하면, 기능적, 심미적 이유 그리고 지속될 치조골 성장 때문에 성인과는 달리 발거와 즉시 임플란트 식립이 동시에 시 행되기 어렵다.

통상적으로 발치를 시행하고 성장완료시기까지 기다 리나, 치조골 성장이 저해되어 이미 저위된 유착 치아의 경우, 발치로 인해 더욱 심각한 골소실이 야기될 수 있다. 또한 보철 수복이 가능한 시기까지 상당 시간이 남아, 추 가적인 치주조직의 퇴축이 야기되므로 적절한 치료 방법 이 아니다. 발치 후 성장이 완료되면 골 이식 등을 시행하 여 결손부위를 수복할 수 있으나 결손부위가 클 경우 그 예후가 좋지 않은 문제점이 있다.

다른 방법으로, 아직 성장이 많이 남은 아동에서 전치 부 개방교합을 개선하기 위해 유착 치아를 그대로 남겨 두고 상방에 치관을 수복하는 것이다. 그러나 이 경우, 차후 유착치 치조골은 수직적으로 성장하지 못해, 치아 저위가 심화되어 심각한 기능적, 심미적 문제점이 야기될 것이다. 보철 수복시, 치아의 길이가 인접치아의 절단연 까지 길어져야 하므로, 비심미적일 수밖에 없다.

때때로 12 -14세 이하의 어린이에서는 기능적, 심미
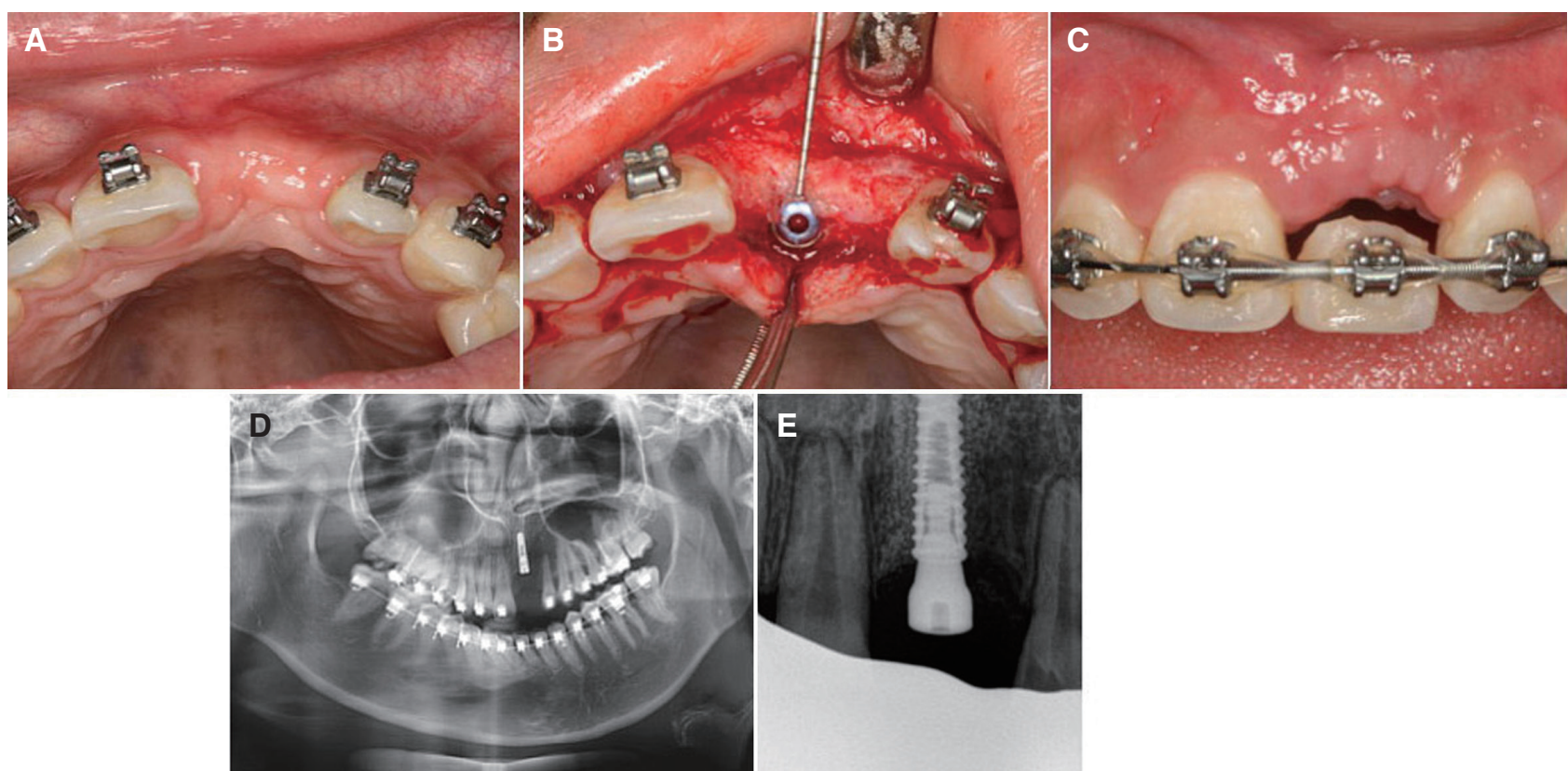

Fig. 9. After 6 months of GBR operation, implantation of fixture. (A, B) Procedure of implant placement. (C) The crown part of \#21 was adjusted to alveolar crest contour. (D, E) Post-operative panoramic radiograph and standard periapical radiograph. 

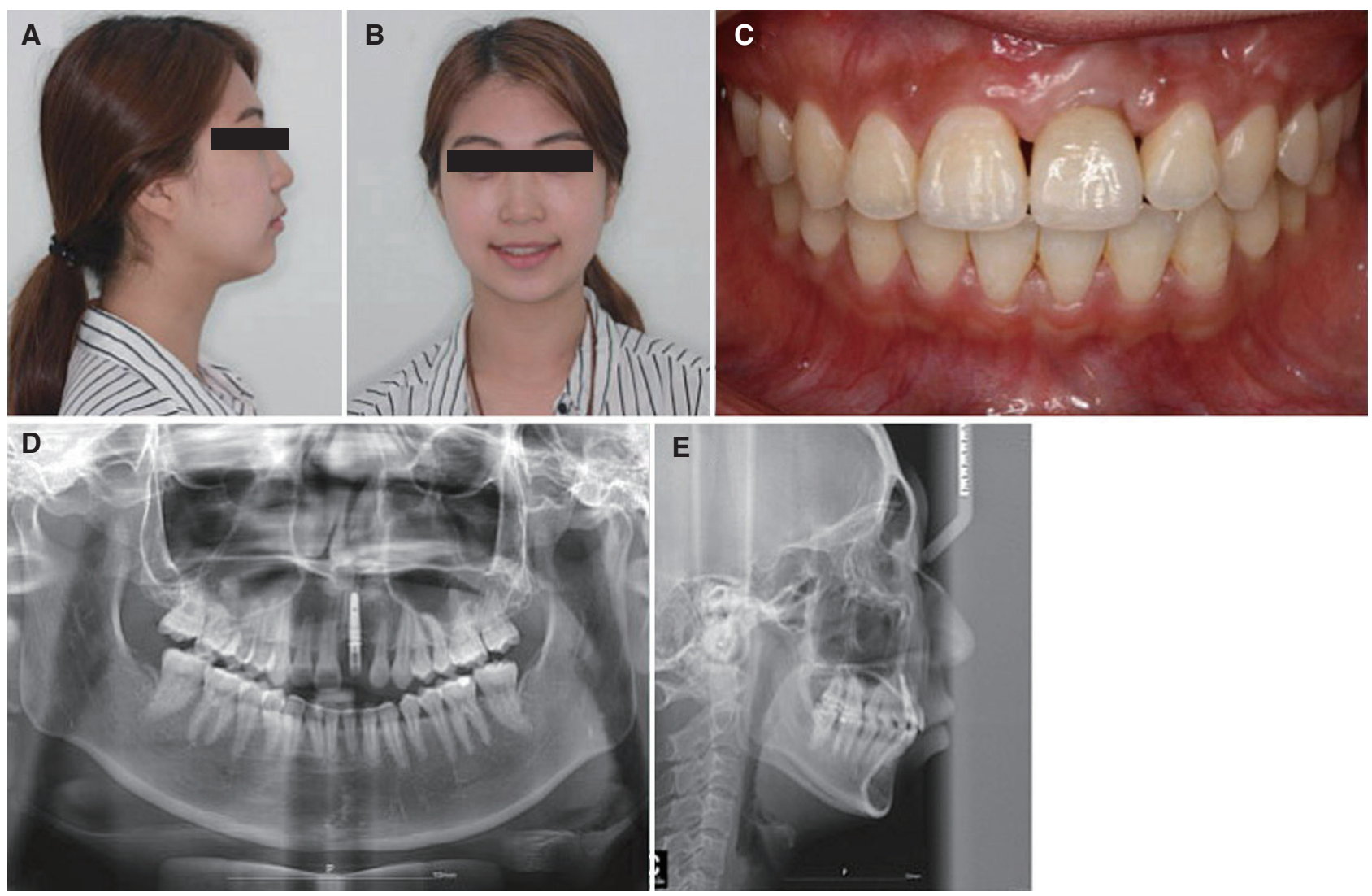

Fig. 10. (A - C) Posttreatment extraoral and intraoral photographs. The final prosthetic restoration of \#21 was performed. (D, E) Posttreatment panoramic radiograph and lateral cephalograph.

적 이유로 건전한 치주인대를 가진 다른 치아의 재식술 이 고려되기도 한다. 특히, 총생으로 인해 소구치를 발거 해야 할 경우 대안적 선택이 될 수 있다. 이 방법을 통해 치조골의 지속적인 성장이 가능해 지기 때문이다. 그러 나 몇몇 보고들에서는 성공적으로 치료하였다고 하나, ${ }^{10}$ 아직 장기간의 추적 관찰이 필요하다. 또한 치근첨이 완 성된 연령에서는 다른 치아의 재식술이 선택되기 어려다. 본 증례에서는 재식을 치관 수복은 임상 치관 길이가 과 도하게 길어져, 비심미적 결과가 예상되어 시행할 수 없 었으며, 교정치료 또한 비발치 치료였으므로 이 방법은 선택되지 못 했다.

그 외 선택될 수 있는 방법이 유착 치아의 외과적 재위 치이다. 이 방법은 수술을 통해 적극적으로 단기간에 유 착치를 원래 자리로 위치시켜 인접치와 수직적 위치를 맞 출 수 있다. 그러나 연조직 신장의 한계, 술후 골편의 치 유를 위한 재혈관화 등의 요소로 치료 전 인접치아와의 치은연이 크게 차이가 나지 않아야 하는 전제 조건이 있 다. 또한 외과적 재위치술은 장기간의 예후가 좋지 못한 데, 퇴축된 치조골은 변하지 않고 유착이 오히려 촉진될
수 있기 때문이다. ${ }^{10}$ 최초 내원시, 본 증례에서는 $8 \mathrm{~mm}$ 이 상의 과도한 치아 위치 변화가 요구되어 이 방법 역시 선 택할 수 없었다.

골신장술은 Ilizarov ${ }^{11}$ 에 의해 고안된 치료방법으로, 외 과적 절단술을 동반하여 절단된 골편에 느리고 점진적인 힘 부여를 통해 절단된 두 골편 사이의 신생골을 형성한 다. 치조골 신장술에서 최상의 치료 시기는 안면 성장이 완료된 이후, 대략 15 세 이후의 여성, 17 - 18세 이후의 남 성이라고 알려져 있다. ${ }^{12}$ 본 증례의 환자는 최초 내원시, 잔여 성장이 남아있을 수 있으나 급격한 성장 급등기는 지났으리라 판단되었으며(CVM stage 5) 유착치와 인접 치간 수직적 위치 차이가 심하였으므로, 기능적, 심미적, 심리적 요소를 고려하여 청소년기에 1단계 치료로써 치 조골 신장술을 시행하였다.

그러나 성장기의 치조골 신장술을 시행하더라도 만약 환자의 안면 성장이 완료되지 않았다면, 수직적인 치조 골의 높이 차이는 인접 치조골의 성장으로 인해 재발할 것이다. 더구나 치조골의 수직적 성장은 안면성장 중에서 도 가장 늦게까지 지속되며, 심지어 성장이 완료되었다고 
판단되는 성인에서도, 교합 관계에 따른 치열의 변화로 치조골의 수동적 수직 성장은 계속 일어난다고 알려져 있다. 따라서 성장기에 치조골 신장술 시행 이후 계속되 는 치조골의 만기 수직 성장은 예측할 수 없기 때문에 시 행 이후에도 유착치의 저위가 재발할 수 있다. 이 때 이의 개선을 위해서 치관 절제술이 고려될 수 있다. 본 증례는 1 단계 치료 전, 이런 내용을 환자에게 고지하고 진행하였 다. 이후 유지 기간 동안 치조골의 잔여 성장으로 유착치 의 저위가 재발하여 성장 완료 후 보철치료 전 치관 절제 술을 2단계 교정치료와 함께 시행하였다.

치관 절제술은 치수내 조직을 제거하고 근관 형성을 시행하면 치수내로 주변 조직으로부터 기원한 혈액 응고 인자가 들어차는 원리를 이용한 술식이다. 이러한 인자 들에 의해 신생골 형성이 일어나며, 이 때 치근은 신생골 형성을 위한 매개체로서 작용한다. 흡수된 치근 상방으 로 얇은 층의 신생골이 형성되며, 치조정에서 새로운 치 주조직이 생성된다. 주변치아의 지속적인 수동적 맹출은 치주조직에 있는 섬유들을 통해 골침착을 유도하게 한 다. ${ }^{13}$ 이 방법으로 치조골의 폭과 높이를 보존할 수 있고, 잔존 치근 상방으로 수직적 골 침착을 기대할 수도 있다. 따라서 임플란트 식립전 치조정 유지를 위한 좋은 방법 으로 고려될 수 있다. ${ }^{14}$

치관 절제술의 적절한 시기는 유착 치아와 인접 치아의 (1/8 to $1 / 4$ is recommended)의 수직적위치 차이와 아 동의 연령, 성별, 성장 양상 등을 고려해야 한다. ${ }^{15}$ 상기 의 환자에서는 유착 및 치경부 외흡수로 인한 pink spot 이 관찰되어 발치 및 보철 치료를 계획하였다. 교합관계 개선을 위해 먼저 교정치료를 시행하고, 교정치료 완료 후 치관 절제술을 시행하였다. 치관 절제술을 통하여 치 근측으로 내려간 치은연을 회복시키고, 임플란트 식립을 위한 GBR을 최소화할 수 있었다. 만일 교정치료 전 발치 를 먼저 시행했다면, 발치 후 심한 협측 치조골 소실로 임 플란트 식립을 위해 block bone graft와 같은 광범위한 골이식을 동반해야 하며, 이후 심미적으로도 불량했을 것이다.

\section{결론}

임상가에게 성장기 아동에서 발생한 유착치를 치료하 는 것은 쉽고 간단하지 않은 일이다. 왜냐하면, 성인과 다 르게 치조골의 성장이 지속적으로 일어나고 있어, 즉시 발치를 시행할 수 없는 상황이 생기기 때문이다. 이 때 다
분야 협력 치료로써 치조골 신장술과 치관 절제술을 적 절히 이용하여 교정치료, 보철치료를 완료한다면, 기능적 및 심미적으로 훌륭한 결과를 얻을 수 있을 것이다.

\section{Acknowledgements}

본 연구는 2017년도 부산대학교병원 임상연구비 지원 으로 이루어졌음.

\section{ORCID}

Eun-young Kwon http://orcid.org/0000-0001-95550360

Woo-Sung Son http://orcid.org/0000-0002-1106-8719

Soo-Byung Park http://orcid.org/0000-0002-9774-9178

Seong-sik Kim http://orcid.org/0000-0003-1988-6043

Yong-il Kim http://orcid.org/0000-0003-3889-2545

Youn-kyung Choi http://orcid.org/0000-0003-1491-

2986

\section{References}

1. Andersson L, Bodin I, Sörensen S. Progression of root resorption following replantation of human teeth after extended extraoral storage. Endod Dent Traumatol 1989;5:38-47.

2. Borssén E, Källestål C, Holm AK. Treatment time of traumatic dental injuries in a cohort of 16-yearolds in northern Sweden. Acta Odontol Scand 2002;60:265-70.

3. Loriato LB, Machado AW, Souki BQ, Pereira TJ. Late diagnosis of dentoalveolar ankylosis: impact on effectiveness and efficiency of orthodontic treatment. Am J Orthod Dentofacial Orthop 2009;135:799-808.

4. Ebeleseder KA, Friehs S, Ruda C, Pertl C, Glockner K, Hulla H. A study of replanted permanent teeth in different age groups. Endod Dent Traumatol 1998;14:274-8.

5. Kinzinger GS, Jänicke S, Riediger D, Diedrich PR. Orthodontic fine adjustment after vertical callus distraction of an ankylosed incisor using the floating bone concept. Am J Orthod Dentofacial Orthop 2003;124:582-90. 
6. Kofod T, Würtz V, Melsen B. Treatment of an ankylosed central incisor by single tooth dentoosseous osteotomy and a simple distraction device. Am J Orthod Dentofacial Orthop 2005;127:72-80.

7. Samchukov ML, Cope JB, Cherkashin AM. Craniofacial distraction osteogenesis. Mosby; 2001. p. 379458.

8. Gound T, O'Neal RB, del Rio CE, Levin MP. Submergence of roots for alveolar bone preservation. II. Reimplanted endodontically treated roots. Oral Surg Oral Med Oral Pathol 1978;46:114-122.

9. Johnson DL, Kelly JF, Flinton RJ, Cornell MT. Histologic evaluation of vital root retention. J Oral Surg 1974;32:829-33.

10. Andreasen JO, Paulsen HU, Yu Z, Schwartz O. A long-term study of 370 autotransplanted premolars. Part III. Periodontal healing subsequent to transplantation. Eur J Orthod 1990;12:25-37.

11. Ilizarov GA. Clinical application of the tension- stress effect for limb lengthening. Clin Orthop Relat Res 1990;(250):8-26.

12. Riolo ML, Moyers RE, McNamara JA Jr, Hunter WS. An atlas of craniofacial growth: cephalometric standards from The University of Michigan School Growth Study. Ann Arbor; The University of Michigan; 1974. p.101-216.

13. Malmgren B, Malmgren O, Andreasen JO. Alveolar bone development after decoronation of ankylosed teeth. Endod Topics 2006;14:35-40.

14. Filippi A, Pohl Y, von Arx T. Decoronation of an ankylosed tooth for preservation of alveolar bone prior to implant placement. Dent Traumatol 2001;17:93-5.

15. Sapir S, Kalter A, Sapir MR. Decoronation of an ankylosed permanent incisor: alveolar ridge preservation and rehabilitation by an implant supported porcelain crown. Dent Traumatol 2009;25:346-9. 


\section{성장기에 발생한 유착치의 치조골 신장술과 치관 절제술을 이용한 심미적 개선 치험례}

권은영 ${ }^{1}$, 손우성 ${ }^{2}$, 박수병 $^{2}$, 김성식 ${ }^{2}$, 김용일 ${ }^{2}$, 최윤경 ${ }^{1,2 *}$

${ }^{1}$ 부산대학교병원 치과진료센터

${ }^{2}$ 부산대학교 치의학전문대학원 치과교정학교실

치아 외상에 따른 흔한 합병증 중 하나는 치아 유착이다. 성인과 달리 성장기 아동에서 유착이 나타날 경우 유착치가 인 접 치조골의 성장을 방해하여 치조골의 발육 부전과 이에 따른 개방 교합을 야기한다. 그러나 저위된 유착치를 단순 발 치할 경우, 성장 완료 시까지 치조제의 상당한 소실을 유발하여 향후 심미적인 보철물을 수복하기가 어려워진다. 본 증례 에서는 성장기에 상악 전치의 유착이 발생한 환자에서 단일 치아 골절단술 후 치조골 신장술과 치관 절제술을 시행하여 상악 전치부의 유착치를 심미적으로 결과를 얻었으므로 소개하고자 한다.

(구강회복응용과학지 2017;33(2):143-53)

주요어: 유착치; 저위 교합; 치조골 신장술; 치관 절제술

*교신저자: 최윤경

(49241)부산시 서구 구덕로 179 부산대학교병원 치과교정과

Tel: 051-240-7430 | Fax: 051-240-7706 | E-mail: youngyng@hanmail. net

접수일: 2017년 1월 10일 | 수정일: 2017년 3월 6일 | 채택일: 2017년 4월 18일 